\title{
A elaboração da face em comunidades virtuais de marca: um estudo de caso sobre uma comunidade virtual de consumidores da Coca-Cola ${ }^{1}$
}

\author{
Concerning face work in virtual brand communities: a case study of a virtual community of \\ Coca Cola consumers.
}

\author{
Grayci Kelli Alexandre de Freitas ${ }^{2}$ \\ André Luiz Maranhão de Souza Leão ${ }^{3}$
}

\begin{abstract}
Resumo
As mudanças por que passam a sociedade e as pessoas, em campos como comunicação, consumo e organização social, desde a concepção da modernidade, colocaram em xeque muitos conceitos que embasavam a compreensão a respeito das pessoas e das suas relações sociais, incluídas as de consumo. Destacamos, neste quadro, as interações sociais encenadas pelas pessoas e os caminhos que percorrem para a elaboração dos seus "eus". Partindo de uma realidade cujo uso massivo da Internet e o surgimento das comunidades virtuais são enfatizados, recortamos uma comunidade virtual da marca Coca-Cola como terreno para compreendermos que faces são elaboradas pelas pessoas quando se utilizam de signos marcários como mediadores em interações virtuais. Para tanto, adotamos as noções de "eu" e elaboração da face conforme concebidas por Goffman (2006), juntamente com a concepção de marca numa dimensão simbólica, enquanto recurso de representação social. Sob este arcabouço teórico, seguimos a perspectiva interpretativista para realizar este estudo de caso netnográfico por meio da análise de discurso funcional. Juntamente com estas orientações ontoepistemológicas e metodológicas, adotamos o método elaborado por Leão (2007) para acessarmos as interações virtuais concebidas como face a face. Catorze faces foram identificadas. Estas são descritas por meio de exemplos extraídos das observações, os quais são elucidativos do papel da marca estudada na dinâmica de negociação interacional entre os participantes, que caracteriza o processo de elaboração de faces. Contribuições para o conhecimento, bem como implicações gerenciais são consideradas.
\end{abstract}

Palavras-chave: Marcas. Comunidades virtuais. Netnografia. Face. Linguagem.

\section{Abstract}

Changes experienced by society and people in fields such as communications, consumption and social organization, since the conception of modernity, have put in check many underlying concepts that help us understand people and their social relations, including consumption. We emphasize in this context the social interactions staged by people and the roads they follow on the development of their own selves. From a reality that makes mass use of the internet, the emergence of virtual communities is common, and we have chosen a Coca-Cola discussion group as a basis for

Artigo submetido em 04 de maio de 2010 e aceito para publicação em 25 de fevereiro de 2010.

${ }^{1}$ Agradecemos o apoio do Conselho Nacional de Desenvolvimento Científico e Tecnológico (CNPq).

${ }^{2}$ Mestre em Administração pela Faculdade Boa Viagem. Endereço: Rua Jean Émile Favre, 422, Imbiribeira, CEP 51190-540, Recife PE, Brasil. E-mail: graycikelli@hotmail.com

3

Doutor em Administração pela Universidade Federal de Pernambuco; Professor Adjunto do Departamento de Ciências Administrativas da Universidade Federal de Pernambuco (DCA/UFPE) e membro permanente do Programa de Pós-Graduação em Administração da instituição (PROPAD/UFPE). Endereço: Av. Prof. Moraes Rego, 1235, Cidade Universitária, CEP 50670-901, Recife - PE, Brasil. E-mail: aleao21@hotmail.com 
understanding which face is developed by people when using brand signs as mediators in virtual interactions. For this purpose, we have adopted the notions of self and face-work as conceived by Goffman (2006), along with the brand concept as a symbolic dimension and a resource for social representation. From this theoretical framework, we follow the interpretative perspective of a netnographic case study using the analysis of functional speech. Along with these ontological-epistemological and methodological guidelines, we adopted the method developed by Leão (2007) to access face to face virtual interactions. Fourteen faces were identified. These are described through examples drawn from observations, which illustrate the researched brand's role in participants' interactional negotiation dynamics that characterize the face-work process. Contributions to the knowledge of the field and managerial implications are considered.

Keywords: Brands. Virtual communities. Nethnografy. Face. Language.

\section{Introdução}

Na sociedade contemporânea, as pessoas adotam os signos das marcas que usam como recurso de construção de suas identidades. Assim, a comunicação entre elas nos remete à noção de identidade, figurando como erigida na alteridade, sob o olhar do outro. Contudo, essa construção não ocorre de maneira unilateral, pois a identidade é fruto da dialética existente entre a pessoa e a sociedade na qual se insere e os tipos de identidade também são produtos sociais. Ao passo que os processos sociais moldam, conservam ou remodelam a identidade da pessoa, esta mesma identidade também exercerá, dialeticamente, a mesma influência sobre a estrutura e os processos sociais (BERGER e LUCKMANN, 2006).

Se, para a pessoa, a realidade só é concebida por meio da alteridade (BERGER e LUCKMANN, 2006) e se o encontro face a face é o canal para desenvolver a sua subjetividade mediante o outro, temos, nas atuais construções de interações verbais ${ }^{4}$ e comunicação, como nas comunidades virtuais, particularmente, um exemplo desse tipo de encontro, contudo, apresentando características inerentes ao ambiente virtual. Neste, as tipificações ou tipos de identidade estabelecida pelas pessoas, quando do encontro com outras, inicialmente anônimas, não serão construídas e nominadas por intermédio das pistas paralinguísticas e não verbais, como ocorre nos encontros face a face habituais. O que ocorre é que a pessoa se revela por outros artifícios, como por textos escritos, fotos e revelação de gostos e preferências - pistas virtuais, digamos.

Nesse contexto, iniciamos nossa pesquisa, cujo principal objetivo visa a compreender quais faces são elaboradas nas interações verbais numa comunidade virtual de consumidores da Coca-Cola. Os critérios para seleção desta comunidade têm base introspectiva, pelo conhecimento da linguagem do falante desta comunidade ou cultura, segundo a linha wittgensteiniana, para a qual os membros das comunidades devem compartilhar do mesmo "jogo de linguagem", definido como aquilo que se insere entre as palavras e o mundo, numa via de mão dupla, dando significado à relação objeto-realidade e caracterizando suas respectivas competências para participar do grupo (LEÃO e MELLO, 2007). Ademais, em se tratando de marca icônica, será maior o contingente a compartilhá-la e mais profundo será seu significado social. Além disso, essa escolha atende ao requisito da etnografia, segundo o qual o pesquisador deve estar inserido na comunidade que estuda, a fim de compreender a linguagem e os significados pertencentes a ela (ROCHA et al., 2005).

Nesta pesquisa, isso se dá consoante a perspectiva da metáfora teatral, já bastante difundida na atualidade, fundada por Erving Goffman (2006), com o intuito de oferecer uma visão mais condizente com a natureza humana e suas complexidades, fugindo de "explicações" simplistas e objetivistas. Assim, sendo a teoria social de Goffman (2006) aquela que guia este trabalho, torna-se imprescindível explicá-la para que fique

4 Nesse contexto, é importante esclarecer que, como estudaremos as interações verbais em ambiente virtual, trataremos, analogamente, linguagem verbal e não verbal como linguagem escrita, com aspectos particulares ao ambiente virtual. 
claro como ela concebe certos conceitos. Entretanto, pelo fato de nesta pesquisa assumirmos uma abordagem sobre o "eu" que não é a mais amplamente adotada nas pesquisas de marketing - ainda que trabalhos de marketing de relacionamento tenham adotado a supracitada metáfora -, antes de explanarmos os principais conceitos que a nortearão, abordaremos como o marketing tem concebido o "eu".

Feito isso, apresentaremos a noção do "eu" conforme desenvolvida por Goffman (2006), que buscou conhecimento para compor boa parte de suas teorias na corrente do interacionismo simbólico, e, em seguida, a própria noção desenvolvida pelo autor.

$\mathrm{O}$ fato de as pessoas utilizarem marcas para construir identidades nos remete, dentro da perspectiva goffmaniana, à teoria da elaboração da face, pois esta elucida, baseando-se na psicologia social, a "etiqueta" adotada para cada situação ou identidade cotidianas, que, por assim dizer, norteia as pessoas inseridas no processo social. Dentro desse mesmo contexto, abordaremos estas elaborações no ambiente virtual, baseando-nos na dinâmica de ameaça/salvamento da face como recurso utilizado, nas interações, para buscar uma imagem positiva de si aos olhos do outro.

Outrossim, sendo a marca um dos pontos importantes para a resposta à nossa problemática, a perspectiva predominante se orienta por uma visão antropológica do consumo, na qual assumimos as marcas em sua dimensão simbólica, ou seja, como signos cujos significados são compartilhados socialmente, isto é, usados como representações de aspectos gerais da vida cotidiana. A esta perspectiva associamos o método de pesquisa elaborado por Leão (2007) e seus aspectos de usos da linguagem, funções da linguagem e atividades marcárias para nos inserirmos no ambiente de uma comunidade virtual da marca Coca-Cola, a fim de concebermos as elaborações da face possíveis geradas pelos usos desta marca nas interações virtuais, oferecendo, assim, uma compreensão de como as pessoas concebem a marca em sua vida.

Pela importância conferida, por esta pesquisa, às atividades marcárias para o marketing como caminhos para melhor entendimento das relações que por elas perpassam, constatamos que o interesse para a área é considerável diante da sociedade do consumo, na qual as marcas se inserem como signos inerentes às interações entre as pessoas e servem à comunicação sobre seus "eus" e sobre o acesso aos "eus" dos outros, donde inferimos a formação e as faces, que, por seu turno, oferecem um novo conteúdo às áreas mencionadas, tanto para enriquecimento das teorias quanto para a aderência de suas práticas.

\section{Construindo uma Concepção do "Eu"}

Na teoria de marketing, a noção de self mais amplamente adotada alinha-se àquela fundada na teoria do autoconceito. Esta abordagem se baseia na divisão entre um "eu" interior e particular e outro "eu" exterior e público e pressupõe a existência de uma unicidade entre estes. Nela, o autoconceito se refere à(s) imagem(ens) que o indivíduo tem de si e é assumido como resultado das experiências sociais dos indivíduos. Sendo assim, é assumido que o comportamento do indivíduo é expresso mediante vários "eus", que se adequam às situações sociais em que este se insere e suas representações se estabelecem. Estes se referem às autoimagens de si (real e ideal) e pelo outro (social e ideal) (SIRGY, 1982; CLAIRBORNE e SIRGY, 1990). Para a administração de marketing, representa um desafio de elaborar e ofertar produtos que sejam "congruentes" com a autoimagem concebida pelo consumidor e com os objetivos sociais que este deseja alcançar.

Outra noção de self que tem se difundido foi proposta por Belk (1988). Tomando como base a definição de William James, de 1890, uma das mais antigas deste conceito, Belk propõe o conceito do "eu" estendido. Seu princípio é de que as posses do indivíduo comunicam sua identidade e fazem parte dela, logo, assume que estes são o que possuem. Nessa concepção, isso ocorre devido à assunção de que aquilo que é "meu" também faz parte do que sou "eu", como, por exemplo, uma parte do corpo. Assim, defende que os indivíduos são a soma de suas posses e articula a importância deste princípio para a compreensão do 
comportamento do consumidor, bem como a influência que este comportamento exerce sobre a existência humana.

No entanto, podemos destacar o crescente interesse pelo entendimento do self por meio do interacionismo simbólico. Schau e Gilly (2003), seguindo a teoria goffmaniana, compreendem o "eu" como sendo formado por uma negociação entre atores sociais para construir uma impressão. O interacionismo simbólico realça a importância dos símbolos e seus significados na formação do self, principalmente por serem elementos unicamente humanos e sociais, uma vez que os símbolos não só surgem das relações humanas e sociais, mas modificam-nos e são modificados nesta relação (GIRARDI JR., 2007; STRYKER e STATHAM, 1985). Isso quer dizer que não há relação de passividade entre o indivíduo e a sociedade; na concepção do interacionismo simbólico; a existência, a construção e a transformação destes estão essencialmente relacionadas ao seu caráter dialético (MENDONÇA, 2001).

Assim, o conceito do "eu" goffmaniano pressupõe o homem, para além dos aspectos biológicos, como um ser construído socialmente pela alteridade. Isso significa que sua identidade se perfaz na assunção de papéis sociais, cujo principal objetivo é conhecer a si mesmo e aos outros (GOFFMAN, 2006).

Diante dessa perspectiva, Goffman compara a realidade a um grande espetáculo teatral, onde os contextos são as cenas, e as pessoas são os atores, que encarnam papéis, entendidos como identidades, a cada respectiva cena do seu cotidiano, a fim de conhecerem a si mesmos e aos outros com quem interagem, de modo mediado ou imediato, e lançando mão de recursos verbais e não verbais (gestos, postura...) para vislumbrar o papel assumido pelos outros e saber quais os respectivos papéis se devem assumir de modo condizente com este cenário. Os aspectos não verbais servem para corroborar um papel assumido, quando "sincero". Contudo, em um papel "cínico", denunciarão a incoerência patente entre o que a pessoa diz e o que seus aspectos não verbais demonstram, uma vez que estes não estão muito próximos da manipulação consciente do ator.

$\mathrm{Na}$ área de marketing, autores como Grove e Fisk (1992) e Grove, Fisk e LaForge (1998) conduzem a teoria de Goffman ao chamado "gerenciamento de impressões" ao afirmarem, da perspectiva da interação teatral, que, aos atores envolvidos, é possível (e recomendado) controlar as variáveis que conduzem a "cena", como tom de voz, expressão facial e outros aspectos desta natureza, desde que embasados em credibilidade e providência, neste caso, como ferramenta para treinamento de pessoas na área de serviços. Além disso, estes autores consideram outro aspecto interveniente nas interações de modo geral, ainda na linha do "gerenciamento de impressões": a presença de outras pessoas, durante um encontro de serviços, que podem interferir, e geralmente o fazem, na qualidade do serviço prestado, pelos mais diversos motivos (GROVE e FISK, 1997). Contudo, Grove e Fisk (1997) reconhecem que o controle da referida situação cabe ao gerente, que deverá ser perspicaz na identificação do contexto e agir de modo a garantir o sucesso do encontro de serviço.

Em nosso trabalho, assumimos o conceito do "eu" goffmaniano e seguimos para o seu conceito de elaboração da face, que será o terreno de desenvolvimento desta pesquisa. Antes de apresentá-lo, no entanto, discutiremos a atualidade da teoria goffmaniana nos estudos das interações ciberespaciais.

\section{A Atualidade da Teoria Goffmaniana no Estudo das Interações Virtuais}

Com a proliferação da utilização da comunicação mediada por computadores (CMC), o interacionismo simbólico tem sido adotado como meio de discutir o problema da corporificação da identidade eletrônica, assumindo que o contexto psicossocial virtual afeta "pessoas reais" (MILLER e ARNOLD, 2003; ROBINSON, 2007). Nesses ambientes, as pessoas recorrem a representações digitais que compensam a ausência da presença física (BOYD et al., 2004; COLLINS, 2008). 
Yates et al. (2007) discutem que a história dos estudos de CMC como área acadêmica começa pela busca do entendimento do papel do anonimato na interação, tendo tais estudos indicado, em referência à teoria goffmaniana, que as características da elaboração da face encontradas nos encontros face a face se mantêm naqueles mediados por computador.

O efeito do anonimato tem sido estudado no uso de avatares (KANG e YANG, 2004). Em relação especificamente ao Second Life, Máximo (2006) afirma que, ao construir o avatar, os participantes elaboram uma representação visual de suas personae no sentido mesmo da noção de pessoa apontado por Goffman. E Pereira et al. (2009) concluem que o participante do Second Life, ao compor seu papel, faz do seu avatar um corpo relacional no ciberespaço, que se constitui no prazer da ilusão dramática.

Para Kim (2004), o trabalho de Goffman sobre como a estrutura social e a realidade são mantidas pelo processo de sanções sociais, encontros situacionais ou sistemas de atividades situadas carrega o sinal distintivo da cibernética.

De fato, desde os primórdios da web, o estudo de Goffman é utilizado para se entender a representação do "eu" na vida eletrônica. Miller (1995) afirma que o ambiente virtual propicia uma gama de recursos expressivos para a representação do "eu" virtual. Nesse sentido, Diniz (2009) estuda os recursos imagéticos e verbais da representação do "eu" no Orkut.

Comunidades virtuais, weblogs, fotologs, chats, salas de conversação, entre outras possibilidades de interação coletiva no ambiente virtual, transportam-se à teatralização da teoria de Goffman para o ciberespaço, funcionando como "janelas" pelas quais indivíduos trocam experiências (LIMA, 2009a).

Em termos goffmanianos, a pessoa por trás do teclado pode ser entendida como um personagem desempenhando um papel (DOORN et al., 2007), construindo seus "eus" virtuais com base em textos e imagens e esperando a opinião do "cyber-outro" para concretizar seu "cyber-eu" (ROBINSON, 2007), que, segundo Cavanagh (2002), é uma criação infinitamente flexível de um indivíduo autônomo, mas que, podemos deduzir, depende da alteridade para realizar este projeto (SANTOS, 2005).

Tendo em vista a tendência de a representação do "eu" ser estrategicamente controlada e idealizada, Cornwell e Lundgren (2001) concluem que o ciberespaço oferece maiores oportunidades para exageros ou mesmo para completos enganos. Nogueira (2007) acredita que é por meio da Internet que as pessoas podem se expor de forma mais segura, evitando ameaças à própria face. Hardey (2002) argumenta que a interação no ciberespaço está mais próxima da visão goffmaniana - de que a interação social ocorre via rituais e normas que protegem o "eu" - do que da imagem de um espaço social revolucionário. Tais aspectos levam à sociabilidade no ciberespaço (BRAGA, 2005; RUTTER e SMITH, 1999).

Por meio de Goffman, também é possível reconfigurar a noção de situação social na mídia eletrônica, definindo-a como um espaço social híbrido, que proporciona interações não apenas entre as pessoas, mas entre elas e a própria mídia (FARIA, 2008; STERNBERG, 2002). Para Robinson (2007), o ciberespaço se configura como um lócus que, em vez de nos libertar de nossas identidades, proporciona a possibilidade de codificá-las. Nesse sentido, busca-se entender o espaço social goffmaniano no ciberespaço (PHILLIPS, 2009).

Vários estudos têm aplicado a teoria social goffmaniana ao entendimento da interação social e da construção de identidades no ciberespaço (GOMES, 2000; LANAMAKI e HENRIKSEN, 2008; PINNELLI, 2002; SCHAU e GILLY, 2003; ZATTI, 2010), incluindo o entendimento da construção de identidades relacionadas a gênero (DOORN et al., 2007; MILLER e ARNOLD, 2003; SANTOS, 2009), a orientações sexuais (COSTA, 2008; LIMA, 2009b; LOMBARDO, 2009), a encontros e sexo virtuais (WANG e LU, 2007; SILVA e SEBASTIÃO, 2002; STOKES, 2007; WHITTY, 2008), a deficientes físicos (LIMA, 2006; TAI, 2007), a culturas pouco conhecidas (ALOMOSH, 2009) ou estigmatizadas (LIRA, 2006; STOKES, 2007), entre tantas possibilidades. 


\section{O Conceito de Elaboração da Face em Goffman}

Em seu artigo "A Elaboração da Face", Erving Goffman argumenta que o "eu" de uma pessoa se constitui de dois aspectos, sendo um produto de suas experiências sociais e moldado por estas, e outro, como uma espécie de jogador, em que utiliza habilidades para ponderar as contingências diárias (GOFFMAN, 1980).

A teoria da face (GOFFMAN, 1980), se caracteriza pela assunção de que as pessoas fazem reivindicações de reconhecimento social e, para tanto, adotam certa linha. Tal linha, por sua vez, se refere a um mecanismo psicossocial utilizado, de forma consciente ou não, por meio das linguagens verbal e não verbal, com o intuito de comunicar aos outros interagentes a avaliação que se constrói destes e de si durante uma interação social.

Uma pessoa apresenta uma linha sempre que se engaja em um encontro social. Esta será o caminho percorrido para a elaboração de uma face, cuja avaliação poderá ser ou não condizente com o que a pessoa endossou para si numa interação. Isto resulta em reações sentimentais, que variam de acordo com a resposta oferecida pelas outras pessoas que interagem na situação, sendo, ainda, produto cultural a carga de sentimentos e a compreensão da interação.

O termo face, advindo do inglês, deriva outros significados para as situações e seus resultados. E, sendo entendida a face como referência tanto à aparência quanto ao autorrespeito, tem-se outras conotações dela produzidas, como "salvar a face" (to save face), envergonhado (shamefaced) e "perder a face" (to lose face), para expressar as reações tomadas pelas pessoas diante do resultado obtido, pelos outros, numa interação social (GOFFMAN, 1980).

O empenho que uma pessoa dedica em zelar por sua face está diretamente ligada à sua manutenção e credibilidade perante seu grupo, uma vez que, se a pessoa não toma ações acerca de sua face no presente, certamente, no futuro, se deparará com maiores dificuldades para o fazer, pois sua credibilidade estará abalada, ao passo que o contrário disso produz uma face consistente e verdadeira aos olhos dos outros interagentes.

Diante do exposto, compreendemos que, ao longo da socialização das pessoas, um acordo tácito, de zelo mútuo pelas suas faces em interações sociais, é aprendido. Em outras palavras, uma pessoa adotará posturas coerentes para preservar a sua face e a face do outro com quem interage, acreditando que, em outras oportunidades, poderá contar com a mesma postura do outro em relação às faces inseridas na interação. Isso significa que, apesar da face ser algo pessoal, a segurança e o prazer de que desfruta são conferidos pela sociedade, por meio de um mecanismo de coerção social, cuja condição para proteger a face e não se ver em situações de constrangimento, é zelar pela face alheia, a fim de obter reciprocidade.

Nas situações em que alguma das partes envolvidas numa interação se vê em situação de ameaça à face, sua ou de outrem, lança-se mão do recurso que Goffman chama de "to save face" (salvar a face). A pessoa pode adotá-lo por vários motivos, entre eles, preservar seu "eu" (self), pelo status que este lhe pode ter conferido; preservar a face dos outros, por motivos de ligações emotivas com estes, por compaixão, por solidariedade. Assim, quando as pessoas se empenham para que a sua elaboração da face e a de outros deem certo, estão legitimando sua socialização. A prática de salvar a face é um artifício habitual e padronizado culturalmente, ou seja, é característica de cada cultura ou subcultura. Saliente-se, ainda, que é necessário perspicácia ou perceptividade por parte das pessoas que pretendem salvar a face, sua ou alheia, para detectar se o salvamento é esperado pelo outro ou se ele ignorará o incidente, que é um dos vários recursos listados por Goffman (1980) quando se refere à elaboração de face adotada pelas pessoas nas interações sociais.

Finalmente, todo este mecanismo social se sustenta pela legitimação de uma ordem social, que é aprendida e incutida pelos indivíduos, como um código de conduta social, cujos fins desejados por uns dependem do seu empenho para que os objetivos dos outros também sejam cumpridos. 
Com base nesta teoria de Goffman, daremos foco à dinâmica de ameaça e salvamento da face em interações no ambiente virtual, conforme detalhado na sessão a seguir.

\section{Comunidades Virtuais de Marca}

As marcas, hoje, expressam algo bem maior que os produtos que lhe deram origem. Por isso, a preocupação da comunicação publicitária voltou-se para significá-las e não apenas anunciar seus produtos (KLEIN, 2008). Apoiada numa comunicação que antes de vender produtos busca vender sentidos, a marca se transformou em uma entidade em si mesma, virando o próprio objeto de troca desejado pelos sujeitos (KLEIN, 2008; PEREZ, 2007; SEMPRINI, 2006). Atualmente, a marca se apresenta como entidade autônoma de comunicação, condição que a impulsionou para a posição de evidência e importância que ocupa no mundo contemporâneo.

Desta forma, no intento de transpor a perspectiva passiva do consumidor apenas como mero receptor pacífico das estratégias das organizações, trataremos, ao longo desta pesquisa, a marca e o "valor de marca" como frutos do consumo simbólico, cuja concepção está no fato de o consumo do produto ocorrer menos pela sua utilidade e mais pelo signo marcário ${ }^{5}$ que ele significa para a coletividade na qual se insere seu consumidor. Ou seja, concebemos as marcas sob a perspectiva sugerida por Leão (2007): são signos marcários que servem às interações humanas e cujos significados são elaborados socialmente, de maneira dinâmica, destacando-se, por isso, o seu valor de uso sobre o habitualmente enfocado pela literatura de marketing, a saber, o valor de troca.

Com esta concepção em mente, consideremos a abordagem das comunidades virtuais, onde é muito incomum o compartilhamento do mesmo espaço físico pelos seus membros, ao contrário das comunidades pré-modernas, em cuja proximidade geografia próxima baseava-se um dos seus princípios (LUEDICKE, 2006). É nesse contexto que se inserem as comunidades de marcas. Na concepção de Muniz e O'Guinn (2001), comunidades de marca têm uma função interpretativa ativa, uma vez que a significação da marca ocorre por meio de uma negociação social e, não, entregue de maneira pronta e inalterada. Nas comunidades de marca, seus membros apresentam maior grau de compromisso e responsabilidade moral com a comunidade, mas não são simplesmente vítimas desavisadas da função de consumo permeada pelas comunidades. Em vez disso, estão em busca, por meio do consumo, de autenticidade e identidade. Por seu turno, Feenberg e Barkadjieva (2004) concebem que, para além do debate sobre a legitimidade das comunidades virtuais, todas as comunidades, na verdade, são imaginadas, pois a virtualidade seria um aspecto inerente à vida cotidiana desde quando as sociedades deixaram de se organizar em pequenas tribos. Para esses autores, são os meios de comunicação adotados pelas comunidades que vão representar como elas são imaginadas, desde a linguagem mais arcaica até os meios eletrônicos em geral.

Para além da noção de comunidades de marca, há que se destacar o rápido desenvolvimento tecnológico experimentado pelas sociedades atuais. Tal aspecto se torna importante na vida das pessoas, a ponto de fazêlas estender sua realidade social ao ambiente virtual, fenômeno que, no contexto das comunidades de marca, é responsável pela produção das comunidades virtuais de marca. Assim, Bagozzi e Dholakia (2002) definem comunidades virtuais como espaços sociais transpostos ao ambiente virtual, mantidos por meio da comunicação contínua entre seus membros, que se reúnem sob o propósito de alcançar objetivos pessoais comuns e compartilhados entre si. Kozinets (1999), por outro lado, define as comunidades virtuais de marcas como resultado da intensidade de dois motivos independentes: a relação do indivíduo com a atividade de

${ }^{5}$ O termo "marcário(a)(s)" é bastante familiar à área de direito (Direito Marcário) e diz respeito ao registro de nomes de marcas; é utilizado de forma corrente também em trabalhos das áreas de comunicação (PEREZ, 2007) e foi inserido na área de marketing, originalmente, por Leão (2007), com o sentido de uma locução adjetiva para "de marca", em todos os casos citados. 
consumo e a relação mantida com membros da comunidade virtual. Quanto maior a intensidade destes dois aspectos, tanto maior será o engajamento do indivíduo na comunidade virtual. Porter (2004), por sua vez, observa que há mais de noventa definições para esta expressão, e consegue extrair destas uma ampla definição. Para ela, comunidades virtuais se compõem por indivíduos ou empresas que compartilham interesses comuns, e cuja interação conta com a mediação de algum tipo de tecnologia e se guia por protocolos e normas.

\section{Procedimentos Método-analíticos}

Nossa orientação para este estudo insere-se na tradição interpretativista, segundo a qual a linguagem é entendida como base da construção da realidade (DENZIN e LINCOLN, 1994). Neste domínio, assumimos uma perspectiva interacionista (BLUMER, 1969).

A pesquisa é caracterizada como um estudo de caso etnográfico (ANDRÉ, 2005) e é inspirada na perspectiva naturalista de Robert Stake, para quem um estudo de caso é, antes de uma metodologia, uma escolha de objeto de estudo. Mais especificamente, esta pesquisa se orienta pelo estudo de caso do tipo instrumental, no qual o caso é secundário, pois sua verdadeira utilidade, após ser contextualizado e aprofundado, é nos ajudar a compreender um interesse maior (STAKE, 1994).

Para tal investigação, realizamos uma etnografia da comunicação. Tal método tem base tanto linguística quanto antropológica, assumindo a comunicação como um meio de dar sentido ao mundo, bem como parte integrante da cultura. Nela, a linguagem é vista como algo que é constrangido pela cultura ao mesmo tempo em que a revela e sustenta. Assim como a etnografia tradicional, a etnografia da comunicação é feita pela observação participante. No entanto, o objetivo do etnógrafo tradicional é aprender sobre uma cultura nativa, de uma forma ampla, por intermédio de seus membros e de como estes dão sentido às suas experiências. Já o etnógrafo da comunicação tem por objetivo fundamental compreender certos aspectos culturais de uma dada comunidade do ponto de vista da interação verbal entre seus participantes, o que veio a ser concebido como uma "comunidade de fala", pelo fato de haver um compartilhamento de seus membros na forma como fazem uso dos signos - linguísticos ou não - da linguagem (HYMES, 1986).

Diante do exposto, há a necessidade, neste trabalho, de um método relacionado à etnografia da comunicação que se encaixe no contexto do ambiente virtual e que atenda o requisito comunicacional já mencionado. Encontramos na netnografia este arcabouço. Método fundado pelo antropólogo e administrador Robert V. Kozinets como uma derivação da etnografia tradicional, porém adequada às características do ambiente das comunidades virtuais, de modo que possibilita a contextualização do comportamento deste consumidor, visto que não ocorre de forma isolada, mas como derivação da vida real, e vice-versa. Assim, recomenda-se o uso da netnografia como método de estudo tanto de comunidades virtuais puras como derivadas, sendo aquelas referentes às ciberculturas resumidas apenas à $\mathrm{CMC}$ (comunicação mediada por computador) e estas a um mesclado de $\mathrm{CMC}$ e vida real, que, neste caso, demandaria outros tipos de métodos complementares à netnografia (KOZINETS, 1998; ROCHA et al., 2005). A netnografia oferece adaptações dos procedimentos de pesquisa para que se acessem as trocas sociais entre os consumidores, no âmbito virtual, além dos métodos tradicionais. Isto se deve à sua derivação da etnografia, com sua adaptabilidade e flexibilidade aos interesses do pesquisador (KOZINETS, 2002).

Na busca por uma forma de acessar a comunicação realizada nessas interações, vislumbramos no ambiente virtual um locus propício para o desenvolvimento de um modo de decifrar o que se encontra entre o dito (escrito) e o não dito (também escrito) pelas pessoas nesses tipos de interação.

Feitas essas considerações, resta-nos apresentar, de fato, o método que elaboramos para alcançar o objetivo desta pesquisa, qual seja, a netnografia da comunicação. Para tanto, partimos do guia para observação e 
análise de interações (face a face) de Leão e Mello (2007), que foi adaptado ao ambiente virtual, e do qual derivamos um novo protocolo (Tabela 1 ).

Tabela 1

\section{Guia para análise de interações virtuais}

\begin{tabular}{|c|c|c|}
\hline & Guia Leão e Melo & $\begin{array}{c}\text { Guia para observação e análise de } \\
\text { interações virtuais }\end{array}$ \\
\hline Acentuação & $\begin{array}{l}\text { "Trata-se da intensidade dada a certos trechos } \\
\text { silábicos e não necessariamente às sílabas tônicas } \\
\text { próprias de cada palavra. Isto quer dizer que não } \\
\text { nos atemos se a acentuação está correta ou não, } \\
\text { do ponto de vista da norma culta" }(2007, \text { p.6). }\end{array}$ & $\begin{array}{l}\text { Trata-se de alterações na escrita das } \\
\text { palavras com acentos tônicos, de modo a } \\
\text { reduzir a quantidade de caracteres ou } \\
\text { símbolos digitados necessários à } \\
\text { construção da palavra. }\end{array}$ \\
\hline Altura da voz & $\begin{array}{l}\text { "A altura da voz refere-se à qualidade do som da } \\
\text { fala relacionada à freqüência de suas vibrações } \\
\text { (aguda, média, grave). Em nossa análise se } \\
\text { caracteriza por ser mais baixa ou mais alta em cada } \\
\text { circunstância" (2007, p.6). }\end{array}$ & $\begin{array}{l}\text { A altura da voz na comunicação de } \\
\text { internet se caracteriza, principalmente, } \\
\text { pelo uso de todas as letras da(s) } \\
\text { palavra(s) em maiúsculo. }\end{array}$ \\
\hline $\begin{array}{l}\text { Duração da } \\
\text { elocução }\end{array}$ & $\begin{array}{l}\text { "A duração da elocução refere-se ao tempo de } \\
\text { articulação do som da fala e varia, de forma } \\
\text { inversamente proporcional, de acordo com a } \\
\text { velocidade de elocução. Toda elocução, } \\
\text { evidentemente, tem uma velocidade e, assim, uma } \\
\text { duração, mas consideramos apenas situações que } \\
\text { contribuem na significação" (2007, p.6). }\end{array}$ & $\begin{array}{l}\text { Refere-se à repetição de letras ou uso de } \\
\text { sinais de reticências no sentido de } \\
\text { alongar a pronúncia da palavra ou } \\
\text { expressão. }\end{array}$ \\
\hline Entoação & $\begin{array}{l}\text { "A entoação refere-se, fundamentalmente, às } \\
\text { formas afirmativa, interrogativa e exclamativa. } \\
\text { Evidentemente, todas as elocuções têm entoações. } \\
\text { Contudo, para efeito de nossa análise, } \\
\text { consideramos aquelas em que a força expressiva } \\
\text { da entoação tenha contribuído na significação" } \\
(2007, \text { p.6). }\end{array}$ & $\begin{array}{l}\text { Caracteriza-se pela utilização dos sinais } \\
\text { de exclamação e interrogação, no } \\
\text { sentido de demonstrar surpresa, dúvida, } \\
\text { espanto e afins. }\end{array}$ \\
\hline Tom & $\begin{array}{l}\text { "Tom é uma inflexão da voz que se refere à } \\
\text { maneira de se expressar. Toda elocução é } \\
\text { acompanha de tons de voz, evidentemente. Mais } \\
\text { uma vez em nossas investigações consideramos } \\
\text { apenas os que contribuem na significação" (2007, } \\
\text { p.6). }\end{array}$ & $\begin{array}{l}\text { Refere-se a expressões que não são } \\
\text { faciais, ligadas ao tom de voz, } \\
\text { geralmente no sentido de suspirar, } \\
\text { opinar, gabar-se, etc. }\end{array}$ \\
\hline
\end{tabular}




\begin{tabular}{|c|c|c|}
\hline $\begin{array}{l}\text { Variações } \\
\text { ortoépicas }\end{array}$ & $\begin{array}{l}\text { "As variações ortoépicas se referem àquelas } \\
\text { dialetais e fonéticas. O primeiro tipo refere-se ao } \\
\text { impacto que diferentes sotaques têm sobre a } \\
\text { pronúncia. A variação fonética, por sua vez, trata- } \\
\text { se dos chamados 'barbarismos fonéticos', ou seja, } \\
\text { palavras soletradas erradamente. Em ambos os } \\
\text { casos, não nos atemos a um sotaque padrão nem à } \\
\text { forma correta, do ponto de vista da norma culta, } \\
\text { de se soletrar as palavras" (2007, p.6). }\end{array}$ & $\begin{array}{l}\text { Este aspecto se refere a mudanças na } \\
\text { escrita das palavras e expressões, com } \\
\text { intuito de reduzi-las, em termos de } \\
\text { tamanho, e de destacar sotaques. }\end{array}$ \\
\hline $\begin{array}{l}\text { Expressão } \\
\text { facial }\end{array}$ & $\begin{array}{l}\text { "A noção de expressões faciais que assumimos se } \\
\text { refere a variações no movimento muscular da face, } \\
\text { que voluntariamente ou não, expressem um } \\
\text { sentimento, comumente emotivo. Podem ser } \\
\text { sorrisos - em suas diversas variedades (desde um } \\
\text { 'ar de riso' até uma 'gargalhada') - ou expressões } \\
\text { com o rosto (tais como caretas, rubor de face etc.)" } \\
(2007, \text { p.6). }\end{array}$ & $\begin{array}{l}\text { Trata-se de palavras e símbolos escritos } \\
\text { de modo a demonstrar expressões } \\
\text { faciais, tais como risos, gargalhadas e } \\
\text { outros, a partir de repetições de letras } \\
\text { ou outros usos de símbolos de uma } \\
\text { forma não habitual; (:P) por exemplo. }\end{array}$ \\
\hline $\begin{array}{l}\text { Movimento } \\
\text { dêitico }\end{array}$ & $\begin{array}{l}\text { "Os movimentos dêiticos são tipos de gestos } \\
\text { específicos. Diferentemente do que chamamos de } \\
\text { gestos, estes são demonstrativos de algo, como, } \\
\text { por exemplo, apontar para algo com o dedo ou } \\
\text { inclinar a cabeça em direção de alguma coisa para } \\
\text { evidenciá-la" (2007, p.6). }\end{array}$ & $\begin{array}{l}\text { Referem-se a expressões escritas usadas } \\
\text { no sentido de demonstrar gestos } \\
\text { específicos que indiquem direção, por } \\
\text { exemplo. }\end{array}$ \\
\hline $\begin{array}{l}\text { Alternância de } \\
\text { código }\end{array}$ & $\begin{array}{l}\text { "São passagens do uso de uma variedade } \\
\text { lingüística para outra, em que os participantes de } \\
\text { uma interação, de alguma forma, percebam como } \\
\text { distintas. Nisto podemos incluir mudanças de } \\
\text { sotaque, de escolhas lexicais, de postura etc. } \\
\text { Apesar de tais aspectos já terem sido considerados } \\
\text { em outras oportunidades, aqui aparecem como } \\
\text { pontos de articulação êmica, em que a alternância } \\
\text { de um código para outro deve ser entendido como } \\
\text { uma demarcação de grupo cultural" (2007, p.7). }\end{array}$ & $\begin{array}{l}\text { Ocorre quando a forma escrita de } \\
\text { alguma palavra ou o uso de aspas nestas } \\
\text { muda o seu sentido habitual, incluindo a } \\
\text { substituição de palavras por números, } \\
\text { por exemplo, cujo uso específico seja } \\
\text { compreendido por um grupo cultural ou } \\
\text { tribo. }\end{array}$ \\
\hline Footing & $\begin{array}{l}\text { "Se refere a uma mudança no alinhamento que } \\
\text { alguém assume para si e para os outros. Em outras } \\
\text { palavras, como, durante uma interação, as pessoas } \\
\text { mudam sua conduta de acordo com o desenrolar } \\
\text { da mesma" (2007, p.7). }\end{array}$ & $\begin{array}{l}\text { Ocorre pelo uso de símbolos ou sinais, } \\
\text { e.g. parênteses, que demarquem } \\
\text { mudança no alinhamento dos } \\
\text { interactantes. }\end{array}$ \\
\hline
\end{tabular}

Fonte: elaboração dos autores.

Quanto à análise propriamente dita dos dados, além das bases conceituais da própria etnografia da comunicação, também foram utilizados os princípios conceituais da sociolinguística interacional (GOFFMAN, 1974, 1981; GUMPERZ, 2002). Esta última, longe de ser uma posição alternativa à primeira, 
apresenta-se como complemento fundamental a ela, dependendo do que se esteja investigando, uma vez que fornece os subsídios para o entendimento de como cada indivíduo se comporta na interação, ou, em outras palavras, como um "eu" interage com outro.

A sociolinguística interacional é acrescida nesta análise etnográfica por dois motivos diferentes. Enquanto esta se ocupa das características culturais de uma comunidade, aquela se dedica a estudar a interação no momento em que ela acontece (LEÃO e MELLO, 2007). É nesse ínterim que identificamos, além da linguagem falada, a linguagem chamada, resumidamente, não verbal, que é fonte de informações não reveladas no discurso falado e matéria-prima para se entender os "eus" (GOFFMAN, 2006) que os sujeitos constroem nas interações valendo-se da competência para o uso dos signos que compartilham no grupo.

Nesse sentido, nossa análise configura-se como um tipo de análise de discurso funcional, ou seja, considera o discurso social como advindo das falas dos sujeitos quando em interação, em que estes geram significado na medida em que os signos são usados conjuntamente (STILLER, 1998).

Sob este panorama teórico, selecionamos uma comunidade virtual da marca Coca-Cola, por figurar como uma marca icônica, o que facilita o acesso às concepções dos interactantes sobre os usos da marca em seus discursos, fortalecendo ainda mais o critério de validade e confiabilidade para a pesquisa, segundo os moldes de pesquisas de cunho qualitativista-interpretativista (LEÃO, 2007). E, entre uma vasta quantidade de comunidades em torno desta marca, escolhemos a que mantinha o maior número de membros cadastrados (1.352.520 membros), qual seja, "Queremos Coca-Cola de 20 litros!", na base do Orkut, que, além de fortalecer os critérios da pesquisa citados há pouco, garantiu uma disponibilidade de dados que nos permitiu atender ao critério de saturação (COSTA, 2007; FONTANELLA et al., 2008). Por se tratar de uma etnografia, estabelecemos o período de coleta em um ano, concentrado entre junho de 2007 e junho de 2008 .

Por conseguinte, detivemo-nos à área de "enquetes" (E) da comunidade, onde encontramos o maior número de interações espontâneas com alusões à marca, encabeçadas pelos membros. A partir de então, dentro de um intervalo de seis meses, selecionamos "telas" (T), dentro das "enquetes" (E), e nos concentramos nos "comentários" (C) postados pelos membros, tudo salvo em arquivos digitais para posterior análise.

Feito isso, passamos a identificar os aspectos da linguagem encontrados nos discursos das interações virtuais coletadas em relação à dinâmica ameaça/salvamento da face. A proposta de procedimento analítico que seguimos foi elaborada por Leão (2007) e sugere que o significado advém de um processo de significação que tem base de inferência na relação de três aspectos, a saber: de forma pragmática, os usos da linguagem, buscando entender a função destes para analisar os atos de fala, que, no contexto desta pesquisa, dizem respeito às atividades marcárias, como objetos discursivos na fala dos interactantes, de modo que se tornam, para além do significado que as marcas carregam, recursos para as interações, neste caso, virtuais, e para a dinâmica de ameaça/salvamento da face.

Por conseguinte, observamos a premissa de que os usos da linguagem têm uma finalidade e que se referem a atos de fala. Assim, a linguagem não verbal e os aspectos interacionais terão funções específicas na linguagem respectiva a cada interação, como, por exemplo, uma expressão facial que denuncia um sentimento ou um contexto que determina o comportamento dos interactantes.

Salientamos, ainda, que a natureza desta pesquisa não se guia pela busca por generalizações, mas sim pela contribuição para a compreensão de uma realidade social. 


\section{Descrição dos Resultados}

Pressupúnhamos que várias faces poderiam ser encontradas durante o estudo. Assim constatado, atribuímos algumas pistas para a compreensão destas, a fim de fugir de definições que possam ocultar a riqueza de suas naturezas, salientando-se que estas faces pertencem ao contexto virtual e da marca e que suas significações foram construídas ao longo da coleta e da análise dos dados, e, também, são inerentes ao contexto em que foram encontradas. Isso, contudo, não impede que outras pesquisas dedicadas ao mesmo assunto encontrem outras faces além das que são aqui identificadas.

Ao longo da apresentação e descrição das faces, ilustraremos seus significados com exemplos advindos da própria coleta de dados desta pesquisa, identificados pelo "localizador" - dado que identifica o número da enquete (E), onde está a tela (T) em que se insere o comentário (C) alvo da análise.

"Do bem": uso de uma marca contrária a outra nomeada "do mal”. Por conseguinte, situações de interação em que uma marca é usada pressupondo a analogia entre bem versus mal, ou afins, culminarão na adoção de uma destas pelos interactantes, de modo que, na tentativa de adotar uma face "do bem", um interactante poderá ameaçar a face do outro que não seguir sua opção, ou salvar a face dele, como a sua, no caso de concordância de ambos sobre o assunto. Configura-se, portanto, um recurso de percepção positiva de um interagente aos olhos do outro pela transferência de uma virtude da marca àquele que a adota, de maneira consequente. Percebe-se, por conseguinte, que este é o propulsor de adoção das marcas na elaboração das faces, conforme continuaremos a constatar nas outras faces.

Esta face pode ser ilustrada quando um membro da comunidade referida (E66T2C2), ao expor sua opção de refrigerante, nomeia uma marca de refrigerante menos famosa (Dolly) como sendo "do mal", pressupondo que a Coca-Cola é "do bem". Portanto, podemos considerar que quem adota a Coca-Cola, neste contexto, visa a elaborar esta face "do bem", transferida da marca para o interagente que a assume.

Abastada: ênfase no valor monetário da marca ou do produto que ela representa, de forma que, quanto mais caro parecer, maior é o interesse do membro por adotá-la e destacar o seu alto preço, demonstrando alto poder aquisitivo. A elaboração da face "abastada" concederá destaque social e financeiro, pois a marca passa a significar, neste contexto, um símbolo de status, servindo à comunicação (sutil) desta condição social, encarada de forma positiva por quem a adota e deseja que os outros a percebam, mesmo que, geralmente, a elaboração desta face implique em ameaça à face de outrem, já que, possivelmente, para que se destaque aquela, faz-se necessário o rebaixamento da opção do outro, para servir de recurso comparativo.

Como exemplo, vejamos o caso descrito no localizador E1T2C7, em que o membro afirma que, em sua cidade, a Coca-Cola custa três vezes mais que o normal e que ele "ainda" acha que está "barato", na tentativa de construir uma face abastada, afirmando que sabe que paga caro em comparação com o preço habitual do produto. Quando utiliza a palavra "ainda", antes de dizer que acha "barato", ele rebaixa a condição dos outros interagentes que apontaram um valor normal para o produto da marca e destaca sua condição "abastada", graças à adoção da marca a um preço mais alto, legitimando a referida face.

Outro exemplo desta face é o descrito no localizador E1T2C5, no qual um membro, ao ser questionado sobre o preço da Coca-Cola em sua cidade, responde: "No mercado é três reais, mas no Cinemark o copo de um litro custa mais ou menos 5 reais!". A pessoa não menciona diretamente, assim como não o fez o interactante do exemplo anterior, mas, ao responder apontando uma marca de rede de salas de cinema (Cinemark) e explicando especificidades do consumo da Coca-Cola ali, ela adota uma face "abastada", pois revela frequentar cinemas que oferecem aquela marca a um preço bem maior do que seria pago fora dali, o que constitui uma situação de salvamento da face deste interagente, pois essa situação é tida como algo positivo por quem pode desfrutar dela.

Autêntica: adoção da marca justificada em atributos como original, única, melhor do que todas as outras, insubstituível, normal, tradicional e afins. Destaca-se por ser a face que se refere, mais proximamente, à 
identidade comunicada, comercialmente, pela marca. Por isso, verificamos vários exemplos de interação da comunidade em torno desta característica da marca e que sempre figuram como tentativas de comunicar esta característica de si pela adoção da marca, constituindo-se a referida face.

A elaboração desta face, por vezes, implica ameaça à face de outrem, durante a interação, pois, em determinada situação, é feita pela desqualificação ou ameaça à elaboração da face de outrem, como um recurso de comparação que favorece quem o utiliza e de modo a legitimar a face elaborada.

No exemplo do localizador E9T1C5, no qual o membro se pronuncia sobre outros refrigerantes, temos: "Coca-zero é horrível nda [nada] substitui a original", situação de face que transfere, como as outras, as características positivas da marca ao seu usuário, salva a face de quem a adota e ameaça as que a contrariam, pelo uso da palavra "horrível" e pela construção comparativa da resposta, que favorece a face autêntica de quem adota a marca Coca-Cola e a enfatiza pelo uso do "nda" [nada].

Vejamos outro exemplo relativo à mesma pergunta do exemplo anterior: "Essa coca zero amarga muito principalmente no final prefiro a nossa coca de todos os dias kkk!!" (E9T1C2). Ora, a despeito de não haver, de fato, nenhum dos atributos mencionados na caracterização desta face, o trecho "a nossa coca de todos os dias" aponta para tais características, pois põe a marca como a habitual, corriqueira, normal, enfim, a única que pode ocupar tal posição nas escolhas e na vida da pessoa. E, ainda, ameaça a face de quem assim não a vê, salvando, por contraposição, a face de quem a encara como tal.

Chique: Ocorre quando a adoção da marca, ou seu produto, refere-se a um comportamento de pessoas "chiques", conferido pela elaboração desta face, que atribui um significado ao uso do signo marcário atrelado ao comportamento diferenciado de pessoas que desejam ser reconhecidas, distintivamente, como tais.

Esta face, por seu caráter distintivo, normalmente, será elaborada em detrimento da ameaça à face de outrem, uma vez que, para demarcar sua distinção, recorrerá, ainda que indiretamente, ao demérito da face de outrem, na interação, com intenção comparativa.

No exemplo do localizador E7T1C6, em que o membro caracteriza o consumo da Coca-Cola como "x-tudo", como "chique", verificamos o atributo transferido a quem adota tal consumo e que constitui ação de salvamento da face desta mesma pessoa, e, consequentemente, ameaça à face do outro que não o faz.

Conhecedor: demonstração de conhecimento sobre uma marca, ou seu produto, pela aquisição do maior número de informações sobre ela, geralmente usadas para justificar uma opção (salvamento) ou ameaçar a face de outrem.

Como exemplo, mencionamos a resposta encontrada no localizador E9T3C5, numa enquete que pergunta se Coca-Cola Zero é igual à normal, e um membro se manifesta: "O gosto refinado para coca ñ me deixa tomar tal coisa, e nem presenciar tal falta de pudor o fato de falarem, que realmente trata-se da tão querida 'cocacola de todos os dias"”.

Em outro exemplo, a pessoa é mais evidente e se autointitula conhecedora, numa resposta à enquete sobre se Coca-Cola faz mal ou não: "na verdade não tem mais na composição da coca-cola cocaína. Os cientistas trocaram por cafeína. SABIA que John Pemberton em 1836 criou a coca e era um remédio pra tosse... ESTÃO FALANDO COM O CARA MAIS INTENDIDO DE COCA, EU!!!! VLW” (E10T1C7).

Observamos que o argumento é uma ameaça à face de quem consome o produto ou a marca, mas salva a face do membro, que usa a informação para construir uma face positiva aos olhos dos outros interagentes.

Defensor: defesa da marca e do seu usuário diante de situações ou argumentos que os ponham em condição de ameaça, como aquelas que mencionam seus malefícios à saúde ou aquelas que comparam os atributos de outra marca, ou produto, e apontam uma desvantagem da marca que os interagentes defendem. 
O caráter desta face pode ser de ameaça ou de salvamento, assim como todos os outros, de acordo com o contexto em que é elaborada. No entanto, em geral, ela se apresenta como tentativa de salvamento da marca e de quem a adota, em resposta a alguma situação de ameaça ou demérito.

Por exemplo, temos a situação em que se questiona, numa enquete, se Coca-Cola faz mal e um membro responde com chacota: "ahsuahusaeu eu tomo tdos os dias... na escola d manhã... no almoço... no lanchinho da tard e nunk fez mal..." (E10T1C4). Em outro exemplo, uma enquete pergunta se Coca-Cola foi o primeiro refrigerante, e um membro responde: "olha se naum doi o primeiro a ser inventado foi o primeiro que prestou pq existe ate hj e todo mundo gosta.........rsrs" (E4T2C1). Percebe-se, neste exemplo, o tom de defesa da marca usado pelo membro no trecho "foi o primeiro que prestou", que culmina numa ameaça às outras marcas e à face dos seus consumidores.

Desapontado: situação de face que funciona, também, como recurso de salvamento quando o indivíduo se propõe a experimentar outras marcas e seus produtos e deseja demonstrar arrependimento depois disso. É uma face, portanto, que serve a quem deseja expor suas experiências sem, contudo, expor sua face à ameaça de parecer controverso aos olhos do outro. Por isso, logo em seguida à elocução na qual conta sua experiência com outra marca, a pessoa recorre a alguma justificativa para tal ato, mesmo que seja atribuindo más qualidades à marca contrária à comentada para salvar a própria face.

Esse fenômeno é visto, por exemplo, no caso de uma enquete que pergunta o que a pessoa acha da CocaCola Zero e um membro responde: "O gosto muda totalmente...já tomei, não gostei, não tomo mais." (E39T2C7). O mesmo pode ser visto no exemplo de uma pergunta sobre se Coca-Cola é igual a Coca Zero e um membro responde: "Acho q a cora zero deixa um gosto estranho na boca depois q toma" (E9T2C1). Ora, é patente, nesta resposta, que o membro experimentou a outra marca e agora se justifica sob o argumento de que "deixa um gosto estranho", com tom de desapontamento pela experiência com a outra marca.

Desinformado: trata-se de uma face que, geralmente, é atribuída pelo outro da interação, em contraposição à face "conhecedor". Também segue acompanhada pela ameaça à face, conforme exemplo a seguir: "quem foi que disse que em minas a coca e 4,00 reais e um burro eu ja combrei lá por 2,50 a dois e 2,30 gelada" (E1T1C1). Constata-se, aqui, uma ameaça à face do outro membro que, em sua resposta, tenha afirmado tal "absurdo", logo desmascarado por ele mesmo, que constrói uma face de "conhecedor", enquanto atribui a face de "desinformado" ao outro membro.

Num outro exemplo, uma resposta à mesma enquete, temos outra resposta: "o cara ai de baixo é louco, estamos falando de coca-cola ele fala de dolly xD" (E1T2C1). Neste caso, a ameaça à face do outro é mais direta, pois é nomeado de "louco", além de lhe ser atribuída, pelo respondente, a face de desinformado, por mencionar outra marca numa enquete sobre a Coca-Cola.

Divertido: refere-se a uma face caracterizada pela descontração, cujas elocuções, normalmente, aparecem acompanhadas por símbolos de expressões faciais ou tom (vide item "uso", no guia para interações virtuais desta pesquisa) ligados a este tipo de situação. Constitui-se recurso de salvamento ou de ameaça à face, de acordo com a situação, mas, principalmente, serve a contextos onde a pessoa deseje ameaçar a face de outrem sem ser ríspida, mas recorrendo ao tom de brincadeira para expor suas opiniões ou, mesmo, salvar sua própria face. Assim, a pessoa salva sua face de um contexto ameaçador anterior a essa elaboração, ao mesmo tempo em que salva a face de uma possível retaliação por parte do outro interlocutor diante da ameaça à sua face, pois o tom de brincadeira serve para aliviar as reações às elocuções. Isso se observa no seguinte exemplo, uma resposta à pergunta sobre se Coca-Cola engorda: "Ai a cola naum engorda keim engorda eh keim bebe..kkk maix msmo assim eu bebO" (E6T1C1).

Em outra resposta, agora à pergunta com que Coca-Cola combina, temos: "Coca combinaa com td! Rsrsrrsrs" (E7T1C2). A sequência "Rsrsrrss" (risada) e o uso da exclamação, ao fim da frase, caracterizam o tom de diversão e descontração conferido à resposta, que se transfere para o membro que a escreve, e ainda tem características de salvamento da face, porque este mesmo tom de diversão também serve para tal. 
Envolvida: diz respeito à face elaborada com elementos de sentimento e apego à marca, numa forte tentativa de representação da identificação do indivíduo com a marca. Em geral, suas elocuções carregam um tom de sentimento exagerado e funcionam como elemento de salvamento da face, sendo pouco usadas para ameaçar a face de outrem, uma vez que sua busca se concentra no sentido maior de destacar a identificação da pessoa com a marca, a fim de estabelecer uma ligação entre esta e a personalidade de quem a adota, mesmo que, para tanto, a relação entre a pessoa e a marca se pareça com a relação afetuosa entre duas pessoas íntimas, que se conhecem e que são parecidas.

Por exemplo, um membro, ao responder uma enquete que pergunta quais ingredientes compõem a CocaCola, em sua opinião, registra: "Amor paixao carinho ternura etc... p ser tao bom assim,so pode ser esses ingredientes." (E70T1C4)

Em outra resposta a uma pergunta sobre com que Coca-Cola combina, temos: "Coca cola combina com tudoo eu amoo" (E8T5C8). Neste caso, o sentimento pela marca ou produto é explicitado ("eu amo"), tamanho o envolvimento que se deseja demonstrar em relação à marca. Esta face, também, configura uma tentativa de salvamento da face de quem a adota, porque seu envolvimento com a marca justifica suas escolhas e opiniões.

Esperto: face elaborada para demonstrar a inteligência da pessoa no uso da marca, ou seu produto, em relação aos usos dos outros. Nesta face encontramos recursos de salvamento, mas, principalmente, de ameaça à face de outro, pois, geralmente, há referência a alguma vantagem, de qualquer natureza, que um interagente tem e o outro, não. Isso pode ser visto no exemplo a seguir: "Eu PrEfIrO A 0!Q pRa nóS MeNiNaS,é mElHoR FiCaR SeM CeLuLiTe!EsSaS bOlInHaS XaTaS!pRiNcIpAlMeNtE Na pRaIa!" (E9T3C1). Aqui, a respondente opta por uma outra marca, distinta da marca da comunidade, ainda que seja apenas uma variação desta, e justifica com o argumento de esperteza, como se esta marca satisfizesse pessoas com preocupações estéticas e saudáveis.

Numa das respostas sobre por quanto se venderia a Coca-Cola de 201, tem-se: "Se caso eu tivesse a dita jóia rara ñ venderia só mostraria e só cobrando ingressos de dez reais e mais dez para poder tocar hahahaha!!!!!!” (E128T4C8). É patente, nesta resposta, a esperteza que o membro faz questão de demonstrar quando responde que cobraria dinheiro das pessoas para deixá-las ver e mais caro ainda para deixá-las tocar na suposta Coca-Cola de 20 litros. Constitui-se, aqui, uma ameaça à face do outro em relação a quem o interactante seria mais esperto.

Flexível: situação de face em que a pessoa se mostra indiferente às opções que lhe são postas, em relação às escolhas da marca e seus produtos. Em geral, carrega um tom de salvamento da face, pois pode vir acompanhada de justificativas, ainda que pouco evidentes, pela(s) escolha(s). Trata-se de uma face adotada para justificar as variações na escolha das marcas, dependendo da situação, ou seja, serve para caracterizar as mudanças nas escolhas de marca da pessoa, que são justificadas pela ideia de que alguém pode gostar e se identificar com mais de uma marca, sem que, por isso, perca a identificação que cada uma delas serve a quem as escolhe.

Vejamos um exemplo: "entre a zero e a original eu gosto mas da original.... meu amigo se ñ tive a original vai a zero.... sendo coca vai a qualquer hora.." (E51T2C8)

Em outra resposta sobre quanto, percentualmente, prefere-se a Coca-Cola em relação a outros refrigerantes, temos: "Banlaciado entre Kuat e Coca-Cola" (E89T1C3). O uso da palavra "Banlaciado" (balanceado) já anuncia que a pessoa não apresentará uma resposta com uma única opção, e, de fato, quando responde com duas possibilidades de escolha, o membro constrói uma face flexível, também servente ao salvamento de sua face, pois não precisa restringir sua resposta a só uma opção, que poderia lhe render mais críticas do que sua provável flexibilidade - esta, por seu turno, abrange aprovação de um número maior de pessoas. 
Irônico: apresenta-se, normalmente, como uma ameaça à face do outro, pois se mostra em tom de resposta a situações que carregam obviedade. Ou seja, esta face serve como recurso de ameaça à face de outrem e reforça uma característica positiva a alguém que consegue elaborá-la, pois esta pessoa está atenta a detalhes do contexto que, talvez, fujam aos outros, e os insere na interação de forma a valorizar sua percepção e inteligência na adoção daquela marca.

Pode-se constatar isso em uma enquete, na comunidade da Coca-Cola, sobre se seus membros gostam de Coca-Cola: "Não, não eu to nessa comu pq eu odeio" (E137T2C7), denunciando, assim, a incoerência de quem elaborou a pergunta e não observou que ela seria óbvia dentro de uma comunidade construída em torno desta marca.

Ilustremos, ainda, com mais uma situação na qual uma enquete verifica sobre a informação de que existe Coca-Cola de $200 \mathrm{ml}$ e um membro lança: "Grande coisa... poden inventar ateh a d uma gota... queremos eh a d 20 litros auhsuahsuahs" (E126T1C2). É evidente a ameaça à face de quem elaborou a enquete pela falta de sensibilidade ao lançar tal pergunta numa comunidade que reivindica que se venda Coca-Cola em recipientes de 20 litros. A evidência reside nos usos "grande coisa" e na risada sarcástica (auhsuahsuahs), que concedem o tom de ironia à resposta.

Leal: caracteriza-se pela ênfase na escolha da marca ou de seu produto, em quaisquer circunstâncias. A elaboração desta face está atrelada à demonstração de identificação com a marca como signo, pois, com elocuções que demonstram lealdade à marca, em qualquer circunstância, as pessoas buscam comunicar aos outros interagentes uma ligação profunda com a marca. Além disso, esta face é mais usada como recurso de salvamento do que de ameaça. Esta última possibilidade não é nula, no entanto, como se vê em: "ehh óbvio, lógico, claro e evidente.. que pepsi pode ser oq for.. ( e a única coisa kii eh::: Horrível..)mas eoO naoO beboO nem se me pagarem..Eh coca-cola.. nao importa de que jeito" (E16T2C5).

Em outra situação, um membro responde, ao ser questionado se Coca-Cola engorda: "EU NOOOM ME PREOCUPA EU GOSTO DELA ASSIM MESMO" (E6T1C1). A despeito da ameaça à saúde e à estética suposta pela pergunta, o membro não renega sua escolha. Ao contrário, enfatiza-a com o uso "assim mesmo", caracterizando, assim, sua lealdade à marca, e, além disso, salva sua face, pela incondicionalidade de sua escolha, pressupondo ameaça à face de quem não agir assim em relação à Coca-Cola.

Racional: demonstrações de racionalidade no consumo, na opção da marca e seus produtos, e, geralmente, com tom de ameaça à face do outro, especialmente daquele que demonstra sentimento exagerado à marca.

Esta face é adotada por pessoas que desejam, assim, renegar que sejam dominadas ou manipuladas pela marca ou pelo consumo, por isso costumam admitir a opção pela marca, mas sempre o fazem de modo a elaborar uma face racional que a projete positivamente, como alguém que tem controle da situação e da sua própria vida. Observemos o exemplo: "O medico dissse q A coca distrói os ossos e q se tu toma di++Morre + cedo" (E143T1C2).

À pergunta "pra vc o que é coca-cola?", encontra-se, em uma das respostas, o que se pode considerar um exemplo de adoção da face racional: "eu não idolátro uma coca gosto bastante mas não dexa d ser só um refri” (E47T2C4). A preferência pela Coca-Cola é constatada na resposta do membro, e, inclusive, na sua participação ativa na comunidade. Entretanto, ele faz questão de enfatizar uma suposta racionalidade em sua opção e consumo da marca ao mencionar "eu não idolatro uma coca..." e "só um refri”, mesmo após afirmar que "... gosto bastante..." Ademais, como já foi mencionado, ao adotar uma face racional, o membro ameaça a face de outrem que não assuma o consumo da marca desta forma, e salva a sua própria face, pois demonstra, ou, pelo menos, deseja demonstrar, que mantém o controle do seu consumo a despeito de todas as investidas de marketing da marca.

Radical: sentimento radical pela marca ou seu produto, fechando espaço para outras possibilidades. A pessoa tenta demonstrar a adoção da marca de forma tão veemente que não abre espaço para outras em seu 
discurso. Dessa forma, temos um recurso que funciona mais como instrumento de ameaça à face de outrem do que de salvamento da própria face.

Vejamos um exemplo: "Todos os dias, o dia todo, a qualquer hora, amo tanto coca cola que não tomo nenhum outro refrigerante." (E78T1C4). Em outro exemplo, ao responder sobre o que é Coca-Cola para ele, um membro desafia: "prefiro Pepsi + mesmo assim eu gosto d coca e quem quiser me xingar pq eu falei isso, fique a vontade" (E47T1C1). A face radical se desenha, principalmente, pela atitude que o membro adota quando, além de optar por outra marca, distinta da que guia a comunidade, ainda desafia quem quiser criticálo. Ou seja, ele adota uma postura radical diante do contexto de concordância em relação à marca Coca-Cola, característica da maior parte da comunidade. Assim, ainda, ameaça a face dos outros, diretamente, porque desafia quem condenar sua opção discordante da comunidade.

\section{Conclusões}

Em nossas análises dos dados da comunidade virtual da marca escolhida, inferimos que as marcas e tudo o que se refere a elas, no contexto da comunidade, tornam-se recursos legitimadores da face que os interagentes ali envolvidos elaboram, dado que buscam demonstrar e se fazer crer que mantêm, de fato, uma identidade com a marca, quer isso seja feito por meio de ameaça à face de outrem ou pelo salvamento da sua própria face, ou do outro, mas, por fim, para construir uma imagem positiva de si aos olhos dos outros.

Ao que nos parece, a influência das marcas na elaboração das faces dos sujeitos tornou-se um processo inerente à socialização nas sociedades de consumo. Dessa forma, podemos inferir que esse processo, ao passo que acirra o individualismo, concomitantemente, depende do coletivismo, porque, quando o observamos em detalhes, identificamos signos (marcas) com significados compartilhados, que funcionam para a elaboração de uma face que seja positiva aos olhos do outro, em ambientes comunitários (virtuais), ainda que num sentido distinto daquele que caracteriza as comunidades primitivas.

Evidentemente, as faces inferidas nesta pesquisa não esgotam todas as possibilidades. Pelo contrário, abrem caminho para um uso gerencial como uma nova opção à construção de marcas e sua relação com os "eus" dos consumidores que deseja alcançar, considerando a dinâmica inerente à elaboração das faces que compõem estes "eus".

Desta forma, entendemos que a presente pesquisa fornece um material de cunho tanto prático quanto teórico às áreas do comportamento do consumidor e de gestão de marcas, pois podem ser compreendidas como uma nova forma de olhar a identidade da marca para a formação dos "eus" dos consumidores. Por um lado, este pensamento sugere que os profissionais de marketing, em vez de determinarem uma única identidade para as marcas que gerenciam, deveriam desenvolver, para estas, diversas características que pudessem se aproximar das elaborações das faces dos seus consumidores e acompanhar suas dinâmicas. Com isto, apresentariam a estes, a marca e suas características de forma maleável, valendo-se da concepção de que os consumidores não possuem apenas um "eu", e sim que este pode variar de acordo com as circunstâncias em que estão inseridos, como aspecto inerente à sua formação social. Por outro lado, tal abordagem se afasta da objetividade e determinação dos sujeitos que geralmente acompanham o processo de composição da identidade e da construção da marca segundo a literatura. 


\section{Referências}

ALOMOSH, A. F. Virtual communities in the Arab World. European Journal of Social Sciences, v. 8, n . 4, p. 569$80,2009$.

BAGOZZI, R. P.; DHOLAKIA, U. M. Intentional social action in virtual communities. Journal of Interactive Marketing, v. 16, n. 2, p. 2-21, 2002.

BELK, R. W. Possessions and the extended self. Journal of Consumer Research, v. 15, n. 2, p. 139-68, Set. 1988.

BERGER, P.; LUCKMANN, T. A construção social da realidade. 26 ed. Petrópolis: Ed. Vozes, 2006.

BLUMER, H. Symbolic interactionism: perspective and method. Los Angeles: University of California Press, 1969.

BOYD, D.; CHANG, M.; GOODMAN, E. Representations of digital identity. Conference on Computer Supported Cooperative Work. Chicago, Nov., 2004. p.6-10.

BRAGA, A. Sociabilidade no livro de visitas: uma dimensão comunicacional da feminidade contemporânea. In: BRAGA, A. (Org.). CMC, identidades e género: teoria e método. Ovilhã: Universidade da Beira Interior, 2005. p. 25 55.

CAVANAGH, A. Behaviour in public? Ethics in online ethnography. Cybersociology, v. 6, 1999.

CLAIBORNE, C. B.; SIRGY, J. M. Self image congruence as a model of consumer attitude formation and behavior: A conceptual review and guide for future research. In: DUNLAP, B. J. Developments in Marketing Science, Proceedings of the Academy of Marketing Science Annual Conference, v. 8, 1990. p. 3-7.

CORNWEL B.; LUNDGREN D. C. Love on the Internet: involvement and misrepresentation in romantic relationships in cyberspace vs. realspace. Computers in Human Behavior, v. 17, n. 2, p. 197-211, 2001.

COSTA, A. M. N. O campo da pesquisa qualitativa e o método de explicitação do discurso subjacente (MEDS). Psicologia Reflexão e Crítica, v. 20, n. 1, p. 65-73, 2007.

COSTA, V. T. As representações da homossexualidade feminina na esfera pública virtual. Dissertação não publicada. Porto Alegre: UFRGS, 2008.

DENZIN, N. K.; LINCOLN, Y. S. Entering the field of qualitative research. In: ; (Org.). Handbook of qualitative research. Thousand Oaks: Sage Publications, 1994.

DINIZ, K. C. L. A construção da imagem de membros adolescentes e/ou jovens do Orkut - uma análise discursiva dos perfis. In: CONGRESSO NACIONAL DE LINGÜÍSTICA E FILOLOGIA, XII. 2008, Paraná. Anais... Rio de Janeiro: CIFEFIL, 2009.

DOORN, N.; ZOONEN, L.; WYATT, S. Writing from experience: presentations of gender identity on weblogs. European Journal of Women's Studies, v. 14, n. 2, p. 143-159, 2007.

FARIA, M. S. As formas virtuais do social - imersão e extensão em ambientes virtuais: Second Life e Barcamp. Dissertação não publicada. São Paulo: USP, 2008.

FEENBERG, A.; BAKARDJIEVA, M. Virtual community: no 'killer implication'. New Media \& Society, v. 6, n. 1, p. 37-43, 2004

FONTANELLA, B. J. B.; RICAS, J.; TURATO, E. R. Amostragem por saturação em pesquisas qualitativas em saúde: contribuições teóricas. Cadernos de Saúde Pública, v. 24, n. 1, p. 17-27, 2008.

GIRARDI JR., LIRAUCIO. Pierre Bordieu - Questões de Sociologia. [s. 1.]. São Paulo: Ed. AnnaBlume, 2007. 
GOFFMAN, E. Frame analysis. Boston: Northeastern University Press, 1974.

A elaboração da face: uma análise dos elementos rituais da interação social. In: FIGUEIRA, S. (Org.).

Psicanálise e Ciências Sociais. Rio de Janeiro: Francisco Alves, 1980. p.76-114.

Forms of talking. Philadelphia: University of Pennsylvania Press, 1981.

A representação do eu na vida cotidiana. 14 ed. Petrópolis: Ed. Vozes, 2006.

GOMES, C. Novos mapas culturais e o ciberespaço. In: CONGRESSO PORTUGUÊS DE SOCIOLOGIA, IV. Anais... Coimbra: Actas do IV Congresso Português de Sociologia, 2000.

GROVE, S. J.; FISK, R. P. The service experience as theater. Advances in Consumer Research, v. 19, p. 455-461, 1992.

.; __ __ LAFORGE, M. C. Developing the impression management skills of the service worker: an application of Stanislavsky's principles in a services context. The Service Industries Journal, v. 24, n. 2, p. 1-14, Mar, 2004.

GUMPERZ, J. J. Convenções de contextualização. In: RIBEIRO, B. T.; GARCEZ, P. M. (Org.). Sociolingüística interacional. São Paulo: Edições Loyola, 2002.

HARDEY, M. Life beyond the screen: embodiment and identity through the internet. The Sociological Review, v. 50, n. 4, p. 570-585, 2002.

HYMES, D. Directions in sociolinguistics: the ethnography of communication. Nova York: Basil Blackwell, 1986.

KANG, H-S.; YANG, H-D. The effect of anonymity on the usage of Avatar: comparison of Internet Relay Chat and Instant Messenger. Proceedings of the Tenth America's Conference on Information Systems. New York, Aug. 2004. p. 2734-2743.

KIM, J. H. Cibernética, ciborgues e ciberespaço: notas sobre as origens da cibernética e sua reinvenção cultural. Horizontes Antropológicos, v. 10, n. 21, p. 199-219, 2004.

KLEIN, N. Sem logo: a tirania das marcas em um planeta vendido. 6. ed. Rio de Janeiro: Record, 2008.

KOZINETS, R. V. On netnography: initial reflections on consumer research investigations of cyberculture. Advances in Consumer Research, v. 25, n. 1, p. 366-371, 1998.

E-tribalized marketing? The strategic implications of virtual communities of consumption. European Management Journal, v. 17, n. 3, p. 252-264, 1999.

The field behind the screen: using netnography for marketing research in online communities. Journal of Marketing Research, v.34, Feb., p. 61-72, 2002.

LANAMÄKI, A.; HENRIKSEN, A. Identity in online communities. In: IRIS, 31. Proceedings... Are: IRIS, 2008.

LEÃO, A. L. M. S. Investigações marcárias: Uma caminhada em busca de compreensão da significação das marcas pelos consumidores inspirada na segunda filosofia de Ludwig Wittgenstein. 2007. Tese (Doutorado em Administração) - UFPE, Recife, 2007.

; MELLO, S. C. B. Apresentando a etnografia comunicação ao campo de pesquisa em administração. In: ENEPQ, 1, 2007, Recife. Anais... Recife: ANPAD, 2007.

LIMA, A. S. Da cultura da mídia à cibercultura: as representações do eu nas tramas do ciberespaço. In: ENCONTRO DE PESQUISA EM COMUNICAÇÃO E CIDADANIA, III. Anais... Goiânia: 2009a. 
. Entre imagens e escritas de si: autorrepresentações de travestis nas tramas do ciberespaço. In: SEMINÁRIO NACIONAL DE PESQUISA EM CULTURA VISUAL, II. Anais... Goiânia: 2009b.

LIMA, T. F. S. A tribo dos surdos no ciberespaço. Monografia não publicada. Juiz de Fora: UFJF, 2006.

LIRA, L. C. Narrativas de Ana: corpo, consumo e self em um grupo pró-anorexia na Internet. Dissertação não publicada. Recife: UFPE, 2006.

LOMBARDO, A. P. Sex and cyberspace: the Internet in the sexual lives of men who have sex with men. Tese não publicada. Toronto: University of Toronto, 2009.

LUEDICK, M. K. Brand community under fire: the role of social environments for the HUMMER brand community. Advances in Consumer Research, v. 33, n. 1, p. 486-493, 2006.

MÁXIMO, M. E. Blogs: o eu encena, o eu em rede - cotidiano, performance e reciprocidade nas redes sócio-técnicas. Tese não publicada. Florianópolis: UFSC, 2008.

MENDONÇA, J. R. C. Interacionismo simbólico: uma sugestão metodológica para a pesquisa em administração. In: ENANPAD, 25, 2001, Campinas. Anais... Campinas: ANPAD, 2001.

MILLER, H. The presentation of self in electronic life: Goffman on the Internet. In: EMBODIED KNOWLEDGE AND VIRTUAL SPACE CONFERENCE GOLDSMITHS' COLLEGE. London: University of London, June 1995.

; ARNOLD, J. Self in web home pages: gender, identity and power in cyberspace. In: RIVA, G.; GALIMBERTI, C. (Eds.). Towards CyberPsychology: mind, cognitions and society in the Internet age. Amsterdam: IOS Press, p. 73-94, 2003.

MUNIZ, A. M. JR.; O’GUINN, T. C. Brand Community. Journal of Consumer Research. v. 27, Mar., 2001.

NOGUEIRA, C. S. Orkut e as comunidades virtuais: identidades solúveis no ciberespaço. In: Congresso Brasileiro de Ciências da Comunicação da Região Norte, VI. Anais... Belém: 2007.

PEREIRA, R. S.; SILVA, M. R.; PIRES, G. L. Representações de corpo e movimento no ciberespaço: notas de um estudo etnográfico no jogo Second Life. Licere, v. 12, n. 2, 2009.

PEREZ, C.. Gestão e semiótica da marca: a publicidade como construção e sustentação sígnica. In: INTERCOM, 30, 2007, Santos. Anais... Santos: Sociedade Brasileira de Estudos Interdisciplinares da Comunicação, 2007.

PHILIPS, D. J. Ubiquitous computing, spatiality, and the construction of identity: directions for policy response. In: KERR, I.; STEEVES, V.; LUCOCK, C. Lessons from the identity trail: anonymity, privacy and identity in a networked society. Oxford: Oxford University Press, 2009. p. 303-18.

PINELLI, S. Internet addiction disorder and identity on line: the educational relationship. In: INFORMING SCIENCE CONFERENCE. Proceedings... Cork, 2002.

PORTER, C. E. A typology of virtual communities: A multi-disciplinary foundation for future research. Journal of Computer Mediated Communication, v. 10, n. 1, 2004.

ROBINSON, L. The cyberself: the self-ing project goes online, symbolic interaction in the digital age. New Media Society, v. 9, n. 1, p. 93-110, 2007.

ROCHA, E. P. QUIMARÃES; BARROS, C.; PEREIRA, C. Perspectivas do método etnográfico em marketing: Consumo, comunicação e netnografia. In: ENANPAD, 24, 2005, Brasília. Anais... Brasília: ANPAD, 2005.

RUTTER, J.; SMITH, G. Ritual aspects of CMC sociability. In: BUCKNER, K. (Ed.). Esprit i3 workshop on ethnographic studies in real and virtual communities. Edinburgh: Queen Margaret University College, 1999. p. 113122. 
SANTOS, H. Alteridade, decepção e estigma no ciberespaço: desdobramentos da interação social mediada. Revista FAMECOS, n. 26, 2005.

SANTOS, L. F. O. Tornar-se homem: dramaturgias em torno das apresentações de si, das emoções e dos afectos em palcos offline e online. Tese não publicada. Braga: Universidade do Minho, 2009.

SCHAU, H.; GILLY, M. We are what we post? Self-presentation in personal web space. Journal of Consumer Research. v. 30, n.3, p.385-404, Dec. 2003.

SEMPRINI, ANDREA. A marca Pós-moderna: Poder e Fragilidade da Marca na Sociedade Contemporânea. São Paulo: Estação da Letras, 2006.

SILVA, C.; SEBASTIÃO, P. Interacção e cibersexo no IRC. In: SILVA, C.; SEBASTIÃO, P. Interacção e ciberespaço. Évora: Universidade de Évora, 2002. p. 23-49.

SIRGY, M. J. Self-Concept in Consumer Behavior: A critical review. Journal of Consumer Research, v. 9, n. 3, dez.1982.

STAKE, R. E. Case studies. In: N. K. DENZIN; Y. S. LINCOLN (Orgs.). Handbook of Qualitative Research, SAGE Publications, 1994, p. 236-247.

STERnBERG, J. The yin and yang of media ecology. The 3rd Annual Media Conference. Ecology Association Convention, Marymount Manhattan College, New York, 2002.

STILLER, G. F. Analyzing everyday texts: discourse, rhetoric, and social perspectives. Thousand Oaks, CA: Sage Publications, 1998.

STOKES, C. E. Representin' in cyberspace: sexual scripts, self-definition, and hip hop culture in black American adolescent girls' home pages. Culture, Health \& Sexuality, v. 9, n. 2, p. 169-184, 2007.

STRYKER. S.; STATHAM, A. Symbolic Interaction and Role Theory. In: LINDZEY, G.; ARONSON, E. (Orgs.). The Handbook of Social Psychology - Theory and Method. 30 ed., v. I. New York: Random House, 1985.

TAI, L. S. Deficientes físicos no Orkut: análise das potencialidades inclusivas da comunidade e suas apropriações. In: COLÓQUIO INTERNACIONAL SOBRE A ESCOLA LATINO-AMERICANA DE COMUNICAÇÃO, XI. Anais... Pelotas: 2007.

WANG, H.; LU, X-A. Cyberdating: misinformation and (dis)trust in online interaction. Informing Science Journal, v.10, p. 1-15, 2007.

WHITTY, M. T. Revealing the 'real' me, searching for the 'actual' you: presentations of self on an internet dating site. Computers in Human Behavior, v. 24, n. 4, p.1707-23, 2008.

YATES, S. et al. Linguistics, Politeness and CMC. In: COMPUTER/HUMAN INTERACTION CONFERENCE. Proceedings... San Jose: 2007.

ZATTI, A. H. Antepassados do Orkut: uma análise da convergência midiática. Razón y Palabra, n. 73, p. 2-14, augoct., 2010 . 